assess the military's latest intelligencegathering technologies, says Philip Coyle, a senior adviser for the Center for Defense Information, who spent seven years as director of the Pentagon's Operational Test and Evaluation Directorate. By scrutinizing media coverage and the defence department's public statements, Coyle hopes to study the success of technologies aimed at telling smart bombs where to strike, such as the new computerized command and control systems, and unmanned aerial vehicles.

Postol and Lewis, meanwhile, will be seeking clues about the performance of the Patriot missile interceptor. After the first Gulf War, the MIT team conducted a frameby-frame analysis of 33 Patriot intercept attempts to determine the altitude, speed and outcome of each engagement. "We were able to get an enormous amount of information from the footage," says Postol. Their analysis showed that at least a third of the Patriots fired during the first Gulf War failed to destroy a Scud missile - demolishing the army's initial claims of a $96 \%$ success rate for the system.

This time the MIT researchers plan to videotape hours of news coverage to track the latest generation of Patriot missiles, known as the Patriot Advanced Capability-3 (PAC-3). Unlike the original Patriots, which used explosives to blow up incoming missiles, the PAC-3 destroys warheads by the sheer force of its collision with them. This 'hit-to-kill' technology is also the basis of the first-generation US ballistic-missile defence system being built in Alaska, heightening interest in the system's performance. Already, the army's central command says that four Iraqi missiles have been intercepted by the PAC-3 system.

Some analysts complain that, even as the Pentagon opens up the battlefield to the press — assigning some 500 reporters to US military units - it is shutting down other data sources. Earlier this year, for example, the US administration began classifying missiledefence test data (see Nature 417, 777; 2002). John Pike, head of Washington-based Globalsecurity.org, says that he used to use commercial satellite images to analyse military activity, but when US troops entered Afghanistan in 2001, the United States bought all of the images so that no one could access them. It is unclear whether the administration will follow a similar course during the present conflict with Iraq, he says.

"The data are getting worse and worse," says Arkin. Nonetheless, Lewis says that his team will continue to scour hours of news coverage to find hints about how weapons are performing. "It's more important than ever to do this because this administration has become so secretive," he says.

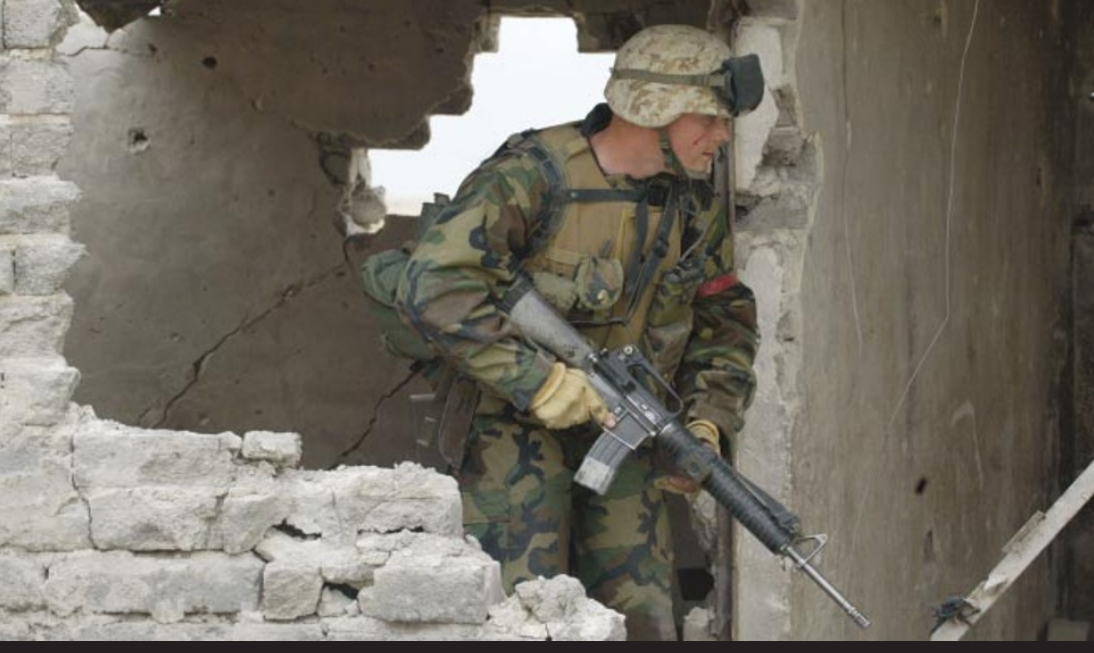

The US may face accusations of hypocrisy if it deploys riot-control agents during street fighting.

\title{
Critics slam US over plans to use riot-control chemicals in the Gulf
}

\section{Jonathan Knight, San Francisco}

As thousands of US troops poured into Iraq last week, an argument was breaking out back home about their possible readiness to use tear-gas or even chemical calming agents during the conflict.

Some military experts argue that riotcontrol agents could help to reduce enemy and civilian casualties, particularly if urban warfare breaks out in the streets of Baghdad. But others contend that the use of chemical agents would violate the 1997 Chemical Weapons Convention (CWC).

These objections were delivered to President George W. Bush and British Prime Minister Tony Blair in a 20 March letter from interest groups including the Union of Concerned Scientists, and Physicians for Social Responsibility. The letter urged the two leaders to outlaw the use of riot-control agents or calmatives in Iraq.

The topic first surfaced on 5 February, when US defence secretary Donald Rumsfeld told the House Armed Services Committee that he was looking for ways to allow commanders in the field to use riotcontrol agents, and implied he would seek presidential approval for such measures.

The United States has a legal framework that could permit such action. After the Vietnam War, the then President, Gerald Ford, ruled that chemical riot-control agents, such as tear-gas, could be used in certain circumstances but only with permission from the White House. One such situation would be to disperse civilians that enemy troops were using as a human shield.

The White House has not said whether such permission has been sought for the current conflict. The Pentagon confirms that chemical smoke and pepper spray have been used in previous conflicts, but declines to say what has been supplied to units in Iraq.

Some observers contend that US forces are carrying more dangerous calmative agents, comparable to the gas used to end a siege in a Moscow theatre last October that resulted in the deaths of over 120 hostages and 41 hostage-takers. "We can document Pentagon research on these agents," says Edward Hammond of the Sunshine Project, a pressure group based in Austin, Texas, that opposes the development of chemical weapons. "I think they are chomping at the bit to use these things," he says.

But the Pentagon denies that such a research programme exists. The Department of Defense "is not pursuing any chemically or biologically based incapacitating agents", says a Pentagon spokesman.

Experts also disagree on whether the use of riot-control agents would violate the CWC. The document's wording covers chemicals that cause "temporary incapacitation", but its real targets are strongly toxic substances such as nerve gases, says Jim Lewis, a senior fellow at the Center for Strategic and International Studies in Washington DC. "It was poor drafting," he says. "As it stands, it includes the mace on your key chain."

Furthermore, proponents of calmative agents argue that non-lethal gases save lives. If enemy soldiers are hiding in a building with civilians, for example, it is safer to drive everyone out than to go charging in, they point out.

Objectors counter that the Moscow incident showed that calmatives can be lethal (see Nature 420, 7; 2002). And some take exception to the use of milder agents such as tear-gas. Mark Wheelis, a microbiologist at the University of California, Davis, says that many countries would see the use of tear-gas to disarm Iraq of chemical weapons as hypocritical. "If the United States uses riotcontrol agents, most of the world would consider it a violation of the CWC," he says. 